
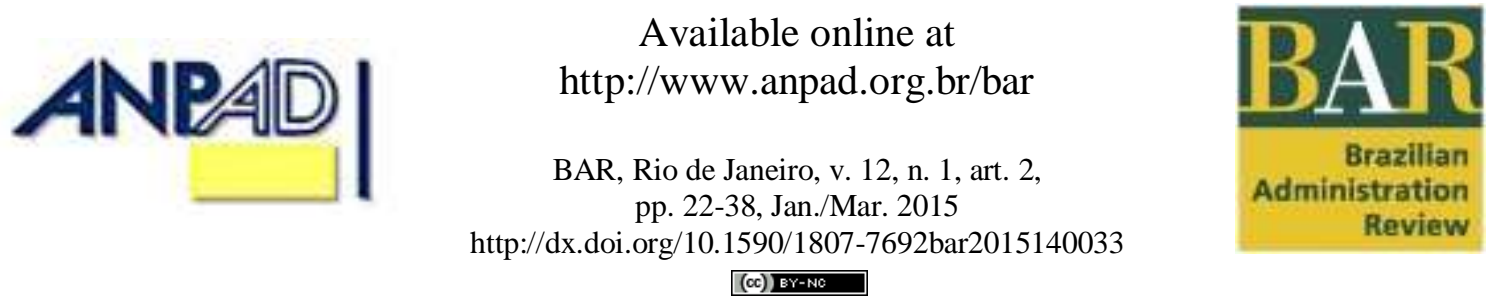

\title{
An Introduction to the 5M Framework: Reframing Change Management Education
}

Richard Badham Macquaire University/Macquarie Graduate School of Management

Vera L. Cançado Fundação Pedro Leopoldo

Temi Darief Macquaire University/Macquarie Graduate School of Management

Received 12 June 2014; received in revised form 26 October 2014; accepted 17 December 2014; published online 17 March 2015.

Editor's note. Tyrone Pitsis served as Action Editor for this article. 


\begin{abstract}
The purpose of this paper is to introduce a reflective and critical rhetorical framework capable of replacing traditional approaches to change management and its education. This framework conceptualises managing change as the Mindful Mobilising of Maps, Masks and Mirrors and provides a comprehensive integration of the processual, practice and critical academic literature on change management. It adopts a drama-tic approach, combining dramaturgical and pragmatic approaches to organisations and change. This paper introduces the framework, the manner of its delivery as an MBA subject, and the varying perceptions of its nature and impact held by a number of mature middle management MBA students who had attended the course. The documentation of student interpretations draws on the learning diaries completed by MBA students in two deliveries of the subject at a leading business school in Australia. It is argued that the framework provides a working model of a reflective and critical approach to change management that resonates with mature managers, and concludes with recommendations for future research and development.
\end{abstract}

Key words: change; rationality; drama; leadership; education. 


\section{Introduction: The Rhetoric of Managing Change}

In recent years, the view of change as a planned linear, episodic, $\mathrm{N}$-step staged process has been supplemented by more pragmatic processual, symbolic, discursive and practice-based approaches (Badham, Antacopalou, \& Mead, 2012; Collins, 1998; Jabri, 2012; Weick \& Quinn, 1999). There is now more widespread understanding and recognition of the chaotic, contested and emergent nature of how change gets done in organisations, a challenging process of managing to change rather than a controlled managing of change. Despite the emergence and diffusion of such ideas in organisational studies, however, their impact on management education and practices has been less extensive.

This impact has been held back by two factors. Firstly, the dominant rhetorics and rituals of modern organisations remain overwhelmingly technocratic in character, prioritising and legitimating decision-making processes that are overly and narrowly rational in their view of action, choice and decision-making (March, 1994). This context generates institutional expectations (and sanctions against alternative approaches) that managing change will be addressed as a technical strategy for implementing and executing strategies, rather than a confronting and reflective process for addressing the conditions that prevent strategies from being implemented. Secondly, critical academic commentary is often perceived as not having contributed to useable knowledge. In Buchanan and Boddy's (1992) terms, proponents of such views often provide no checklists.

What we term the $5 \mathrm{M}$ framework has been developed as a rhetorical vehicle to help address this situation by adopting what Kenneth Burke (1984) refers to as a perspective by incongruity; i.e. a process of verbal atom-cracking that works subversively within the existing set of ideas about change, pointing to what has been termed the beyond, within (Long, 2010). This framework has been developed and delivered over the last 10 years to over 1,000 senior and middle managers attending an executive development program and MBA course on managing change at the Macquarie Graduate School of Management, ranked by the AACSB as the leading business school in Australian.

The purpose of this paper is to introduce the rhetorical framework, as an intellectual framework and an interpreted phenomenon. As described in the first part of the paper, the framework is intended to be drama-tic in character, combining dramaturgical and pragmatic approaches to organisations and change. As uncovered in the interpretive study, this general drama-tic character was recognised and positively received, although there were variations in the level and degree to which this was understood and valued. In conclusion, the paper argues that the nature, delivery and reception of the $5 \mathrm{M}$ framework provides a working model of a non-traditional approach for educating managers in managing change, a stimulus for a similar examination of alternative frameworks, and suggestive guidelines for further systematic research on such frameworks and their impact.

\section{The 5M Framework}

The 5M framework builds, on yet alters, the traditional view of the change-management process as a technical control strategy of planning, execution and evaluation. It does so by characterising it as a cultural art of influence in developing and deploying (Mindfully Mobilising) Maps, Masks and Mirrors. This planned change process is still described in traditional and widely resonant terms of a practical plan-do-check or action learning cycle, but in both imagery and content shifts the terms of discussion and debate by characterising and exploring these in cultural terms as the use of Maps, Masks and Mirrors. It also develops upon and transforms traditional overt and popular views of the management in managing change (Mintzberg, 2009), as the expert role of applying techniques and allocating and staffing roles and responsibilities, by viewing the management of change as a complex cultural and political practice of acting mindfully and mobilising energy. In this way, the $5 \mathrm{M}$ framework replaces thin views of the management of change as a formally rational process of applying techniques, allocating formal roles and responsibilities, planning change, executing it and evaluating progress by thick views 
of managing to change as involving being Mindful of complexity and barriers, Mobilising energy and support, Mapping out directions, skilfully putting on and taking off Masks to ensure an effective performance, and creating and using Mirrors in a way that overcomes the cultural and political factors that obstruct the giving and receiving of information.

\section{Through thin and thick}

The traditional mainstream literature on the management of change reflects and reinforces what Buchanan and Boddy (1992) and Buchanan and Badham (2008) characterise as the frontstage public performance of change, a rhetoric of administration (March \& Olsen, 1983) intertwined with the legalrational legitimation of modern bureaucratic domination and control (Weber, 1947). In contrast to what Geertz (1973) describes as the symbolic, multi-leveled, polysemic and situated thick description of cultural meanings, these rhetorics and rituals of the modern rational organisation portray change programmes in thin instrumental, formalistic, one-dimensional and universal terms (Foss, 2001; Kotzee \& Wanderer, 2008; Waltzer, 1994; Zafirovsky, 2003). Such thin interpretations of change programs view them through a functionalist lens (Heracleous \& Barrett, 2001) as unitarist, acontextual and narrowly rationalistic in character (Collins, 1998). This public orthodoxy is dominated by mechanistic and organic metaphors (Morgan, 1980). The dominant formal rhetorics and rituals of change programs construe them as planned interventions employing scientific techniques to bring about the execution of clearly defined strategic goals of system alignment and/or improved organizational health. This is the foundation of the classical Organization Development approach (Beckhard, 1969; Bennis, 1969; Schein, 1969) as well as many N-step models of managing change as following a sequence of planned stages (Collins, 1998). Just as Hendry (1996) remarks, that when you scratch any account of stages of change, you find Lewin's three-stage model not far beneath the surface, so when you unpack the formal rhetorics and traditional episodic views of change (Weick \& Quinn, 1999), it is this thin and narrowly rational view of change programs that underlies them.

The 5M framework, however, provides a thick view of the rationality underlying practices and processes of managing to change (Badham et al., 2012). It brings to the surface the predictable irrationality of individual and organizational decision-making (Ariely, 2008; March, 1981), the ambiguity and chaos in individual and organizational behaviour (Stacey, 2012; Weick, 2000), as well as the tacit, messy and emergent nature of the practice of getting things done (Pfeffer, 1994; Weick \& Quinn, 1999). Its purpose is to move managers from thin preconceptions (of applying techniques and staffing change roles in a plan-do-check cycle) to the appreciation of Mindful action and the Mobilisation of energy and support (in generating Maps, deploying Masks and using Mirrors in a complex, contested and interactive change journey).

In contrast to thin views of planning, execution and evaluation, the $5 \mathrm{M}$ framework provides thick views of the selective, experimental and iterative process of Mapping (Jabri, 2012; Weick, 2000), the complex and interactive nature of wearing Masks in the performance of roles (Fuda \& Badham, 2011; Grint, 2001), and the challenging subjectivity, defensiveness and selectivity involved in the use of Mirrors (Argyris, 2010; Sense, 2008). Similarly, in direct contrast to the view of change knowledge as applied technique and the allocation of change roles as a process of staffing of formal positions, the $5 \mathrm{M}$ framework directs attention to Mindful action (Langer, 1990; Weick \& Sutcliffe, 2001) and the motivation and Mobilisation of self and others (Bruch \& Vogel, 2011; Buchanan \& Badham, 2008) at all moments in plan-do-check (maps-masks-mirrors) cycles.

\section{Organizations-as-drama}

The 5M framework's advocacy of a thick approach to rationality and change is reinforced and informed by a drama-tic view of change practice as a dramaturgical (drama-) and pragmatic (-tic) social performance. The $5 \mathrm{M}$ framework incorporates the insights of what we shall term strong and weak views of organisations-as-drama (Alexander \& Smith, 2003), combining a dramaturgical view of organisations like drama, an approach commonly associated with Erving Goffman (1959), with a dramatism view of organisations as drama as advocated by Kenneth Burke (1969). 
Goffman (1959) style dramaturgy, using the metaphor of theatre to illuminate social performances, provides an accessible introduction to the impression management - the performative dimensions of the interactive external conversation - required in the management and leadership of change. Goffman's emphasis on stagecraft and the arts of influence and persuasion captures this strategic surface dimension of organisational life. Dramaturgy, in this sense, is impression management. Frontstage and backstage performances are used as a metaphor, for organisational action, but it is assumed that organizational reality and the theatrical stage are different things (Kärreman, 2001). This is commonly characterised as the view of organisations being like theatre (Schreyogg \& Hopfl, 2004). As a framework for analysing the mechanics of human interaction and performance, rather than interpreting its meaning, dramaturgy offers what Alexander and Smith (2003) term a weak view of social life as performance.

Burkean dramatism, in contrast, provides what Alexander and Smith (2003) term a strong view. Drama is not viewed as a metaphor for human action but is seen in literal terms (Brock, Burke, Burgess, \& Simons, 1985), as a metonymy (Czarniawska-Joerges, 1997). In contrast to the weak view, this perspective is often described as viewing organisations as drama (Schreyogg \& Hopfl, 2004). Drama is regarded as inherent to human action, as a central component of meaning, motivation and what it is to be human. In this sense, social life is seen as made up of dramatic acts/actions, and dramatism provides us with a closer look at the internal as well as external conversations that occur within this drama - the intertwining of motivation, the cultural narratives and scripts that define who we are and how we should behave, and the play of rhetoric and ritual in shaping how we define situations and exhort ourselves and others to act in new and different ways.

Acting Mindfully about change requires sensitivity to gaps between intention and outcome, to take into account the barriers to change and also to admit its complex character. In accordance with the Goffmanesque weak approach, this is a discipline that has many similarities with improvisational theatre, a creative (making do) and spontaneous process (of letting go) (Kanter, 2002; Vera \& Crossan, 2004). Improvising means to be aware about the unexpected rather than routinely applying techniques, resembling musicians playing jazz. As Mangham and Pye (1991, p. 79) stated

Like jazz musicians, managers simultaneously discover targets and aim at them, create and follow rules, and engage in directed activity often by being clearer about which directions are not right than about specified final results. Their activity is controlled but not predetermined.

In terms of a strong drama approach, acting Mindfully means being aware of rhetorical and ritual dynamics, sensitive to the expressive characteristics (Edgley, 2003) of homo performans (V. R. Turner, 1985), the limitations of the selective perceptions of oneself and others, and able to reflectively monitor performances during action and change (Harre \& Secord, 1973). As Edgley (2003, p. 7) stated "Human beings are not only expressive, but often aware of their expressiveness". It means to be aware of the powerful overly-rational mythologies that structure our expectations of organisations and how they perform (Meyer \& Rowan, 1977).

Mobilizing energy, people, and resources to overcome the gap that often occurs between required and given resources for change is seen within the weak drama as akin to the production and direction of stage plays. The production of a play implies complex interactions between playwrights, producers, directors, and actors, in the context of negotiations to get funding, address theatrical agents, create distribution channels, arrange releases to the press and so on (Mangham \& Overington, 1983, 1987). In contrast, Mobilisation as drama in the strong view is about the character and use of rhetorically and ritually constructed motivations. It requires an examination of the perspective, power and practices involved in energising participants through understanding and capturing situational vocabularies of motive, and achieving identification with symbolic objects and rituals (Alexander, 2004).

The Mapping of change as a journey is, in terms of the weak view of drama, similar to the planned staging of performances; i.e. it involves the creation of scripts and the required components of a mis-enscène that will result in a successful theatrical performance. For the strong view of drama, the Mapping of change is, in a fundamental sense, preparing the rhetorical and ritual dimensions of transition ritual. 
This involves the initial separation of the participants from everyday life and their previous existence, guiding them through the liminal phase, and creating sustainable change by embedding participants within a new structural and cultural frame (V. W. Turner, 1982).

Mapping journey will not, however, lead to change unless managers/practitioners successfully perform change in practice. This means influencing people in interpersonal situational encounters. In terms of the weak view of drama, this is akin to employing techniques of stagecraft, putting on and taking off costumes and Masks, in order to effect a meaningful impression on an audience (Weick, 2000). This performance is required to provide the audience with an impression consistent with the desired goals of the change (Goffman, 1959), and the actor/manager has to be aware of the impression management he is using and the impression he is creating. For the strong view of drama, this process is not similar as much to a theatrical performance, as it is, in essence, the enactment of rhetoric and ritual. It involves the conduct of more or less resonant performances characterised by the fusion or re-fusion of an emotional connection between audiences, actors and text (Alexander, 2004). While overlapping strongly with the weak view of this performance as being akin to theatre, what the strong view adds is a recognition of the ways in which the fragmentation of a complex modern society makes it difficult to achieve resonant transition rituals, and it explores the institutional contexts and internal conversations as well as interpersonal interactions involved in making possible a successful re-fusion of scripts, direction, actors, backstage and frontstage regions, mis-en-scène, and audience (Alexander, 2004).

Finally, looking in Mirrors, creating and using them to provide useful reflections on managing change, is regarded by the weak view of drama as akin to rehearsing and reviewing a theatrical performance. It involves setting up rehearsals, monitoring the responses and reactions of audiences, and shaping, obtaining and adapting to reviews (Clark \& Mangham, 2004; Mangham \& Overington, 1983). For the strong view of drama, as Freire (1987) puts it, what is involved is the basic social process of having to learn how to write your life, as author and witness of history. In this sense, institutional change is inevitably dominated by established and emergent rhetorics, and involves liminal spaces in-between more-or-less orderly social environments (V. W. Turner, 1982). The effective use of Mirrors in the change process is, within the strong view, regarded as part of what McCloskey (1994) and Lanham (1993) characterise as general rhetorical processes of toggling between looking through a text and looking at it. It also focuses attention on the cultural freedom made possible by liminal spaces to creatively and proactively influence the transition process (V. W. Turner, 1982). This framework is summarized in Table 1.

Table 1

The Components of the 5M Framework

\begin{tabular}{|c|c|c|c|c|}
\hline & Thin Rationality & Thick Rationality & $\begin{array}{c}\text { Weak } \\
\text { Like Drama }\end{array}$ & $\begin{array}{c}\text { Strong } \\
\text { As Drama }\end{array}$ \\
\hline \multirow[t]{2}{*}{$\begin{array}{l}\text { Mindful } \\
\text { Change Agency }\end{array}$} & $\frac{\text { Applying }}{\text { Technique }}$ & Acting Mindfully & $\begin{array}{l}\text { Improvising } \\
\underline{\text { Theatre }}\end{array}$ & $\begin{array}{l}\text { Rhetorical/Ritual: } \\
\text { Awareness }\end{array}$ \\
\hline & $\begin{array}{l}\text { Effective tools } \\
\text { and techniques - } \\
\text { OD expert } \\
\text { toolkit }\end{array}$ & $\begin{array}{l}\text { Be careful with the } \\
\text { gaps, barriers and } \\
\text { complexity; } \\
\text { recognize the role of } \\
\text { emotions, politics } \\
\text { and competing } \\
\text { commitments }\end{array}$ & $\begin{array}{l}\text { Expecting the } \\
\text { unexpected; } \\
\text { creative and } \\
\text { spontaneous } \\
\text { process like jazz }\end{array}$ & $\begin{array}{l}\text { Homo performans; } \\
\text { able to reflective } \\
\text { monitor } \\
\text { performances during } \\
\text { action and change }\end{array}$ \\
\hline
\end{tabular}


Table 1 (continued)

\begin{tabular}{|c|c|c|c|c|}
\hline & Thin Rationality & Thick Rationality & $\begin{array}{c}\text { Weak } \\
\text { Like Drama }\end{array}$ & $\begin{array}{c}\text { Strong } \\
\text { As Drama }\end{array}$ \\
\hline \multirow[t]{2}{*}{$\begin{array}{l}\text { Mobilising } \\
\text { Change Roles }\end{array}$} & Designing Roles & Mobilizing Energy & $\underline{\text { Producing Plays }}$ & $\begin{array}{l}\text { Rhetorical /Ritual: } \\
\text { Motivation }\end{array}$ \\
\hline & $\begin{array}{l}\text { Allocating and } \\
\text { aligning change } \\
\text { tasks in formal } \\
\text { roles. }\end{array}$ & $\begin{array}{l}\text { Being proactive in } \\
\text { creating resources; } \\
\text { creating energy for } \\
\text { required thought, } \\
\text { emotion, action and } \\
\text { reflection. Build } \\
\text { motivation and } \\
\text { create coalitions }\end{array}$ & $\begin{array}{l}\text { Orchestrating and } \\
\text { resourcing } \\
\text { directors, writers, } \\
\text { actors, reviewers } \\
\text { and audiences }\end{array}$ & $\begin{array}{l}\text { Motivating and } \\
\text { creating ritual } \\
\text { engagement; power } \\
\text { and practices in } \\
\text { creating identification } \\
\text { with symbolic objects } \\
\text { and rituals; } \\
\text { understand and } \\
\text { influence } \\
\text { vocabularies of } \\
\text { motive }\end{array}$ \\
\hline \multirow[t]{2}{*}{$\begin{array}{l}\text { Maps } \\
\text { Planning Change }\end{array}$} & $\underline{\text { Planning Projects }}$ & $\underline{\text { Mapping Journeys }}$ & $\begin{array}{l}\underline{\text { Staging }} \\
\underline{\text { Performances }}\end{array}$ & $\begin{array}{l}\text { Rhetorical /Ritual: } \\
\text { Preparation }\end{array}$ \\
\hline & $\begin{array}{l}\text { Define goals and } \\
\text { ways to achieve } \\
\text { the; identify a } \\
\text { sequence of } \\
\text { planned stages }\end{array}$ & $\begin{array}{l}\text { Mapping as an } \\
\text { orienting device; } \\
\text { change as } \\
\text { unpredictable } \\
\text { journey; surfacing } \\
\text { the iceberg; } \\
\text { reflective use of } \\
\text { concepts }\end{array}$ & $\begin{array}{l}\text { Directing and } \\
\text { planning staged } \\
\text { productions; } \\
\text { achieving } \\
\text { resonance through } \\
\text { alignment of } \\
\text { actors, scripts, mis- } \\
\text { en-scene \& } \\
\text { audiences }\end{array}$ & $\begin{array}{l}\text { Creating rhetoric and } \\
\text { establishing ritual } \\
\text { practices to support } \\
\text { people through the } \\
\text { separation, liminality } \\
\text { and incorporation } \\
\text { phases of a chain of } \\
\text { transition rituals }\end{array}$ \\
\hline \multirow{3}{*}{$\begin{array}{l}\text { Masks } \\
\text { Leading Change }\end{array}$} & $\underline{\text { Executing Tasks }}$ & $\underline{\text { Wearing Masks }}$ & Employing & Rhetorical /Ritual: \\
\hline & & & $\underline{\text { Stagecraft }}$ & $\underline{\text { Enactment }}$ \\
\hline & $\begin{array}{l}\text { Managers pursue } \\
\text { goals by } \\
\text { executing } \\
\text { planned change } \\
\text { tasks }\end{array}$ & $\begin{array}{l}\text { Exercising influence } \\
\text { through effective } \\
\text { social performances; } \\
\text { giving performances } \\
\text { that address } \\
\text { contradictory } \\
\text { interests and } \\
\text { perspectives, as well } \\
\text { as inherently } \\
\text { paradoxical issues }\end{array}$ & $\begin{array}{l}\text { On stage } \\
\text { impression } \\
\text { management; } \\
\text { interactive } \\
\text { improvisation in } \\
\text { ensuring resonant } \\
\text { performances; } \\
\text { timely donning and } \\
\text { removing of masks }\end{array}$ & $\begin{array}{l}\text { Addressing the } \\
\text { barriers to successful } \\
\text { enactment due to the } \\
\text { complexity, plurality } \\
\text { and fragmentation of } \\
\text { modern society. } \\
\text { Creating re-fusion of } \\
\text { actor/script/audience }\end{array}$ \\
\hline \multirow[t]{2}{*}{$\begin{array}{l}\text { Mirrors } \\
\text { Learning Change }\end{array}$} & $\frac{\text { Evaluating }}{\underline{\text { Outcomes }}}$ & $\underline{\text { Looking in Mirrors }}$ & $\frac{\text { Rehearsing \& }}{\text { Reviewing }}$ & $\frac{\text { Rhetorical/ Ritual: }}{\underline{\text { Toggle/Liminal }}}$ \\
\hline & $\begin{array}{l}\text { Monitor against } \\
\text { objectives and } \\
\text { plans; identify } \\
\text { whether planned } \\
\text { actions have been } \\
\text { conducted, and } \\
\text { outcomes } \\
\text { achieved; } \\
\text { propose } \\
\text { necessary } \\
\text { corrective actions }\end{array}$ & $\begin{array}{l}\text { Being open and } \\
\text { reflective in } \\
\text { establishing effective } \\
\text { learning spaces; } \\
\text { surfacing tacit and } \\
\text { contested knowledge }\end{array}$ & $\begin{array}{l}\text { Setting up } \\
\text { rehearsals, } \\
\text { monitoring the } \\
\text { responses and } \\
\text { reactions of } \\
\text { audiences, and } \\
\text { shaping, obtaining } \\
\text { and adapting to } \\
\text { reviews }\end{array}$ & $\begin{array}{l}\text { Establish toggling } \\
\text { between looking } \\
\text { through a text (or } \\
\text { performance) and } \\
\text { looking at it; use the } \\
\text { cultural freedom of } \\
\text { liminal spaces to } \\
\text { question established } \\
\text { assumptions and } \\
\text { change mindsets. }\end{array}$ \\
\hline
\end{tabular}




\section{Background and Delivery}

The origin of this $5 \mathrm{M}$ framework lies in a twenty-year period of theoretical reflection and action research on the management of change (Dawson, 2003). Over the last ten years, however, it has been developed and refined in an MBA Managing Change subject and Executive Development course at the Macquarie Graduate School of Management. During this time, it has informed over 1000 change action research projects undertaken by experienced senior managers working in, predominantly, large Australian service companies. To explore the nature and outcome of the 5M framework as a rhetorical vehicle, we will draw on a study based on two deliveries of the Managing Change subject built on the framework.

The course consists of 5 days of 8 hour classes, divided into two weekends. Between 20 and 30 students are arranged around tables, in groups of 4 to 5 students, and work together in all the course activities. The 5M Framework is introduced during two weekends using four pedagogical techniques.

Firstly, a highly interactive and image-laden set of lectures by the lecturer, using song, pictures, videos, and cartoons embedded in a Keynote presentation. These are presented in a playful and entertaining manner that is, at the same time, disruptive and challenging to thin views of rationality and models of change management education that draw on such a view. These take up approximately 90 minutes each day. Day 1 introduces the students to the first two Ms of Mindfulness and Mobilising. Days 2 and 3 introduced them to the third M of Mapping, with Masks and Mirrors delivered on Days 4 and 5 on the second weekend.

Secondly, on the second day, a day-long computer based internet simulation takes place, allowing the students to work in their groups to design, and be evaluated on, a successful change program for a fictional case study company GlobalTech. This simulation is based on a particular version of the reflective three-stage view of change embedded in the Mapping component of the 5M framework. The simulation is introduced and debriefed in the same interactive lecture style as occurred on the other four days.

Thirdly, on the fourth day, the exploration of the Masks theme is first conducted through the use of a motivational speech drawn from the movie Braveheart, which is followed up by a Brechtian Verfremdung type use of the video (i.e. "interrupting habitual seeing and thinking, creating a state of temporary incomprehension, and leading to critical insight", Darief, 2011, p. 143). This is undertaken through, initially, the substitution of a female for a male voice in a re-run of the video and, subsequently, the turning off of the sound, leaving the students observing the effect of physical actions, staging and props. This film is followed up by a Boalian (Boal, 1979) theatrical exercise involving students enacting and re-enacting similar scenes in contrasting motivational and de-motivational skits, and commenting on the lessons to be drawn from their presentations. This use of drama is, again, introduced and debriefed in the same whole-group interactive lecture style format.

Fourthly, throughout each of the days, other than the second day, use is made of a controversial, entertaining and emotive video-case study of change (Jamie Oliver's School Dinners) as a basis for applying the knowledge acquired from the interactive lecture sessions and the course readings. The case study takes the form of $4 \times 60$ minute videos, which are delivered towards the end of each day. The students work in separate groups in applying the concepts of Mindfulness, Mobilising, Maps, Masks and Mirrors to the analysis of the case. They are asked to present their findings in interactive largegroup sessions facilitated by the lecturer. The videos are used to provide a dramatic and impactful chaotic, emotive and political illustration of change management, support the playful and creative yet challenging approach to the subject exemplified in the interactive lectures, and provide both a source of entertainment after a long day and a material case study for analysis that takes the students away from their everyday taken-for-granted business experiences.

For evaluation, the students are examined on the basis of individual Learning Diaries and Action Projects, as well as a Group Learning Diary \& Reflections on Action Projects. The Learning Diary is a 
report by the students on their thoughts, feelings and action-reflections that occurred during the course delivery. The aim of the Learning Diary is to provide them with an active learning process that encourages reflection on the overall lessons of the course, individual learnings and their overall learningjourney. The Action Projects provide the students with an opportunity, and requirement, to apply the $5 \mathrm{M}$ framework in their workplaces, and initiate and reflect on real-world action projects that are of importance and are either personally significant to them and/or important for their careers. While the internet simulation, dramatic re-enactments and Jamie Oliver case study take the students away from their everyday work experiences, the action project applies the learning back within their immediate work (and sometimes personal) environment. The Group Learning Diary \& Reflections provided the basis for students to discuss and share learning from the course and their projects. The students are strongly encouraged to write up their Learning Diaries, particularly their overall reflection on the course, as well as their Group Reflections as a creative piece of work. They are encouraged to submit their overall interpretations and key themes in the form of images, narratives, music, sculptures, dramatised performances, artwork and games. This has three main purposes: firstly, to provide them with the opportunity to exercise the kind of artistry and creativity necessary to ensure resonant and effective leadership and change performances (Alexander, 2004; Grint, 2001); secondly, to represent, in the evaluation process, the focus on the below the waterline issues of identity, culture, emotion and politics that the course affirms are central components of organisational change and its management; and, thirdly, to assist students in getting out of their heads, and respond in an emotive, bodily and situated way to the learnings they have obtained and how they might employ them.

\section{Audience Interpretation and Response}

In an important sense, the above is a view of the framework and its delivery from the viewpoint of the author and the actor, not the audience. While course evaluations average 4.5 out of 5 (i.e. fifty per cent rating the course and lecturer as good; and fifty percent as excellent), the learning diaries reveal a variety of different responses to the framework. While it is not possible to separate the effects of the framework from its specific delivery, and the impact of the lecturer, an analysis of the learning diaries does provide an insight into the span of interpretations - ranging from a traditional thin view of rationality and weak view of drama and performance, to thick views of rationality and a strong view of performance.

What follows are perceptions and interpretations drawn from a random selection of 47 learning diaries (20 female, 27 male) from two deliveries of the MBA course in a 12 month period. The average age of the students whose diaries were analysed was 28 years (full-time, $80 \%$ of the class) and 33 years (part-time, $20 \%$ of the class). These were mostly middle-managers with work experience, many with an engineering or information technology degree. They are provided here in order to capture the ways in which the framework, and its meaning, were understood and variably interpreted by different members of the class. On the one hand, these comments provide a practical lay interpretation and insight into the meaning of the framework. On the other hand, they reveal how such a framework may be variably interpreted by different groups, as they are more or less surprised by and open to the more radical thick rationality and strong performance dimensions of the framework. An illustration of such interpretations is provided in the summary of extracted quotes from the learning diaries in Table 2. 
Table 2

Audience Interpretations: Diary Reflections

\begin{tabular}{|c|c|c|c|c|}
\hline & Thin Rationality & Thick Rationality & $\begin{array}{c}\text { Weak } \\
\text { Like Drama }\end{array}$ & $\begin{array}{c}\text { Strong } \\
\text { As Drama }\end{array}$ \\
\hline & Applying Technique & $\underline{\text { Acting Mindfully }}$ & $\begin{array}{l}\text { Improvising } \\
\text { Theatre }\end{array}$ & $\begin{array}{l}\text { Rhetorical/Ritual: } \\
\underline{\text { Awareness }}\end{array}$ \\
\hline $\begin{array}{c}\text { M } \\
\mathbf{i} \\
\mathbf{n} \\
\mathbf{d} \\
\mathbf{f} \\
\mathbf{u} \\
\mathbf{l}\end{array}$ & $\begin{array}{l}\text { "[I expected] to be shown a } \\
\text { model of how to make } \\
\text { change work easily, } \\
\text { effectively and efficiently". } \\
\text { “... equipment to embark ... } \\
\text { on a change initiative at } \\
\text { work ... to fill up } \\
\text { management tool boxes". } \\
\text { "Learn a number of models } \\
\text { which can be applied to the } \\
\text { outside world to create } \\
\text { order". } \\
\text { "The videos were quite a } \\
\text { powerful tool to demonstrate } \\
\text { the dynamics of change". } \\
\text { "As we watched it [the } \\
\text { video], I placed the change } \\
\text { frame on and it became very } \\
\text { interesting at how all the } \\
\text { ideas and concept". } \\
\text { "I am looking for tools, } \\
\text { something like '10 Steps to } \\
\text { Managing Change', a kind of } \\
\text { methodology/ practical } \\
\text { application." }\end{array}$ & $\begin{array}{l}\text { "My thinking of change prior } \\
\text { to the course was orientated } \\
\text { towards execution of process. } \\
\text { I couldn't have been more } \\
\text { naïve on this point." } \\
\text { "I need to look deeper into the } \\
\text { situation and ensure that I } \\
\text { have considered as many } \\
\text { elements as I can identify". } \\
\text { "[i]n change management } \\
\text { programs, the change agents } \\
\text { in the team are so task focused } \\
\text { and self-absorbed that they are } \\
\text { not aware of what is occurring } \\
\text { in the surrounding } \\
\text { environment. The agents ... } \\
\text { are so immersed in running } \\
\text { their own agendas, that they } \\
\text { fail to take notice of their } \\
\text { stakeholder's engagement } \\
\text { levels". }\end{array}$ & & $\begin{array}{l}\text { "Knowledge of } \\
\text { change strikes me } \\
\text { now as a wise } \\
\text { mans art". }\end{array}$ \\
\hline \multirow[b]{2}{*}{$\begin{array}{l}\text { M } \\
\mathbf{o} \\
\mathbf{b} \\
\mathbf{i} \\
\mathbf{l} \\
\mathbf{i} \\
\mathbf{z} \\
\mathbf{i} \\
\mathbf{n} \\
\mathbf{g}\end{array}$} & Designing Roles & $\underline{\text { Mobilizing Energy }}$ & $\underline{\text { Producing Plays }}$ & $\begin{array}{l}\text { Rhetorical /Ritual: } \\
\text { Motivation }\end{array}$ \\
\hline & $\begin{array}{l}\text { "In my view he [Jamie } \\
\text { Oliver] had missed a great } \\
\text { opportunity ... he did not } \\
\text { consider all stakeholders } \\
\text { "the course has too much } \\
\text { focus on leadership and } \\
\text { motivation in the actual } \\
\text { delivery, rather than } \\
\text { spending time assessing and } \\
\text { practising building a case for } \\
\text { the change." }\end{array}$ & $\begin{array}{l}\text { "Interesting that credibility is } \\
\text { something that holds managers } \\
\text { back from trying to make } \\
\text { change. Many of the other } \\
\text { students conceded to this and I } \\
\text { found that surprising, because I } \\
\text { have always pushed myself to } \\
\text { learn from the failure and keep } \\
\text { going until I get it right." } \\
\text { "Apparently this is often } \\
\text { forgotten... you always } \\
\text { understand the emotions that } \\
\text { its in fact more important than } \\
\text { anything..." } \\
\text { "I have always separated } \\
\text { organisational and personal } \\
\text { change and did not realise that } \\
\text { the process and emotions you } \\
\text { go through are the same." }\end{array}$ & $\begin{array}{l}\text { [In the role-play] } \\
\text { "while I was the } \\
\text { frontman there was } \\
\text { a lot of work in the } \\
\text { group around } \\
\text { content, structuring, } \\
\text { props and so on." }\end{array}$ & $\begin{array}{l}\text { "Whilst } \\
\text { recognizing the } \\
\text { powerful effect } \\
\text { leadership } \\
\text { performance can } \\
\text { have on people, I } \\
\text { realize that } \\
\text { change agents } \\
\text { need to have basic } \\
\text { measures in place } \\
\text { to motivate } \\
\text { others". }\end{array}$ \\
\hline
\end{tabular}


Table 2 (continued)

\begin{tabular}{|c|c|c|c|c|}
\hline & Thin Rationality & Thick Rationality & $\begin{array}{c}\text { Weak } \\
\text { Like Drama }\end{array}$ & $\begin{array}{c}\text { Strong } \\
\text { As Drama }\end{array}$ \\
\hline \multirow{3}{*}{$\begin{array}{l}\mathbf{M} \\
\mathbf{a} \\
\mathbf{p} \\
\mathbf{S}\end{array}$} & $\underline{\text { Planning Projects }}$ & Mapping Journeys & $\begin{array}{l}\text { Staging } \\
\underline{\text { Performances }}\end{array}$ & $\begin{array}{l}\text { Rhetorical /Ritual: } \\
\text { Preparation }\end{array}$ \\
\hline & $\begin{array}{l}\text { "In the Global Tech Case } \\
\text { study, the core problem was } \\
\text { identified as lack of } \\
\text { departmental integration. } \\
\text { We selected a number of } \\
\text { tactics and [a] few are } \\
\text { listed". } \\
\text { "Reflecting on my } \\
\text { experience in the Australian } \\
\text { Army, I now realised how } \\
\text { important the creation of a } \\
\text { sense of urgency was in this } \\
\text { change process." }\end{array}$ & $\begin{array}{l}\text { "Day three [Mapping] further } \\
\text { cemented the notion that } \\
\text { change is unpredictable, } \\
\text { however with a map we would } \\
\text { be given orientation and } \\
\text { guidance for our change } \\
\text { initiative ... Further these } \\
\text { maps will allow for reflection } \\
\text { and a chance to discuss } \\
\text { whether there should be a } \\
\text { change in direction in the near } \\
\text { future." }\end{array}$ & $\begin{array}{l}\text { "I feel that the role } \\
\text { of mask setting is } \\
\text { vitally important." }\end{array}$ & $\begin{array}{l}\text { "I understand } \\
\text { now that I didn't } \\
\text { actually know } \\
\text { how my staff } \\
\text { viewed the } \\
\text { current state and } \\
\text { whether their } \\
\text { perspective was } \\
\text { similar to mine". }\end{array}$ \\
\hline & Executing Tasks & Wearing Masks & $\begin{array}{l}\text { Employing } \\
\underline{\text { Stagecraft }}\end{array}$ & $\begin{array}{l}\text { Rhetorical /Ritual: } \\
\text { Enactment }\end{array}$ \\
\hline $\begin{array}{c}\mathbf{M} \\
\mathbf{a} \\
\mathbf{s} \\
\mathbf{k} \\
\mathbf{S}\end{array}$ & $\begin{array}{l}\text { "I need a template to } \\
\text { memorise and apply in every } \\
\text { single situation!" } \\
\text { [The course] "helped me to } \\
\text { apply the techniques and } \\
\text { effectively manage those } \\
\text { changes and formulate the } \\
\text { strategy for the future". } \\
\text { "Unconsciously follow[ing] } \\
\text { the three step process of } \\
\text { change management. I } \\
\text { unfroze the dynamics and } \\
\text { habits of the old team ... then } \\
\text { continued with the moving } \\
\text { stage ... and the team } \\
\text { continues to perform } \\
\text { strongly, a clear sign of } \\
\text { successful refreezing." }\end{array}$ & $\begin{array}{l}\text { "What really struck me [in the } \\
\text { Braveheart clip] was ... seeing } \\
\text { it with a female voice of not } \\
\text { great conviction delivering the } \\
\text { words. ... It confirmed for me } \\
\text { a long- held belief that how } \\
\text { you deliver your message is as } \\
\text { important as the message } \\
\text { itself." } \\
\text { "I kept thinking of a manager I } \\
\text { had worked with before who } \\
\text { seemed to embody many of } \\
\text { the characteristics } \\
\text { encompassed in the 'Leading' } \\
\text { categories. Up until this point, } \\
\text { I had never really rated this } \\
\text { manager very highly... I } \\
\text { realise now that his greatest } \\
\text { strength was his ability to } \\
\text { influence those around him..." } \\
\text { "My challenge with wearing } \\
\text { masks well is not letting my } \\
\text { emotions impact or alter } \\
\text { delivery against planned } \\
\text { performance" }\end{array}$ & $\begin{array}{l}\text { "Through watching } \\
\text { the Braveheart clip } \\
\text { as well as in class } \\
\text { demonstration it } \\
\text { was made clear } \\
\text { how different body } \\
\text { language, } \\
\text { confidence, ... tone, } \\
\text { pausing, ... and } \\
\text { expression can } \\
\text { impact a } \\
\text { discussion." } \\
\text { "I did take a lot } \\
\text { away about } \\
\text { identifying which } \\
\text { elements \& } \\
\text { performances were } \\
\text { persuasive." } \\
\text { [Masks are helpful } \\
\text { for] "hiding some } \\
\text { of my own } \\
\text { emotions and ... } \\
\text { adapting to a } \\
\text { communication } \\
\text { style appreciated by } \\
\text { the audience rather } \\
\text { than displaying my } \\
\text { emotions". }\end{array}$ & $\begin{array}{l}\text { "[This of course] } \\
\text { went over well } \\
\text { with the group ... } \\
\text { and they gave us a } \\
\text { hard time for the } \\
\text { rest of the } \\
\text { afternoon ...This } \\
\text { situation made me } \\
\text { consider how we } \\
\text { treat people, how } \\
\text { quickly we make } \\
\text { judgement on } \\
\text { what may be } \\
\text { complex issues } \\
\text { and how readily } \\
\text { we put on the } \\
\text { mask that suits." }\end{array}$ \\
\hline
\end{tabular}


Table 2 (continued)

\begin{tabular}{|c|c|c|c|c|}
\hline & Thin Rationality & Thick Rationality & $\begin{array}{c}\text { Weak } \\
\text { Like Drama }\end{array}$ & $\begin{array}{c}\text { Strong } \\
\text { As Drama }\end{array}$ \\
\hline & Evaluating Outcomes & Looking in Mirrors & $\begin{array}{l}\text { Rehearsing \& } \\
\text { Reviewing }\end{array}$ & $\begin{array}{l}\text { Rhetorical/ Ritual: } \\
\text { Toggle/Liminal }\end{array}$ \\
\hline $\begin{array}{c}\mathbf{M} \\
\mathbf{i} \\
\mathbf{r} \\
\mathbf{r} \\
\mathbf{0} \\
\mathbf{r} \\
\mathbf{S}\end{array}$ & $\begin{array}{l}\text { "My strategy would be to } \\
\text { develop a checklist with } \\
\text { which I can evaluate how I } \\
\text { progress through the } \\
\text { implementation". }\end{array}$ & $\begin{array}{l}\text { "I do not feel confident } \\
\text { enough, I think that it is a long } \\
\text { process". } \\
\text { "Taking a good hard look at } \\
\text { myself, I can see that I have } \\
\text { certain habits that I need to } \\
\text { navigate away from or } \\
\text { change" } \\
\text { "This (MAP) has been an area } \\
\text { that I need to work on as I } \\
\text { recently found myself to be } \\
\text { very rigid with my plans." } \\
\text { "I was questioning myself to } \\
\text { manage bigger change } \\
\text { programs and a team of } \\
\text { Change Managers. I did not } \\
\text { reflect enough on how I was } \\
\text { making decisions ..." }\end{array}$ & $\begin{array}{l}\text { "Day } 4 \text { [role play] } \\
\text { just gave me the } \\
\text { confidence ... to } \\
\text { understand why this } \\
\text { [use of voice, body } \\
\text { language and } \\
\text { staging] was } \\
\text { needed" } \\
\text { "[The rehearsed } \\
\text { role plays] } \\
\text { encouraged me to } \\
\text { not be afraid [of } \\
\text { testing out } \\
\text { influence } \\
\text { strategies]". } \\
\text { "The role play } \\
\text { reminded me how } \\
\text { preparation is really } \\
\text { important for } \\
\text { building } \\
\text { confidence. Practice } \\
\text { is important too" }\end{array}$ & $\begin{array}{l}\text { "I noted, } \\
\text { afterwards, how } \\
\text { hyped I was after } \\
\text { this talk - I feel it } \\
\text { was partly nerves } \\
\text { and partly the } \\
\text { power of the } \\
\text { group ... [t]he } \\
\text { presentation } \\
\text { worked well and } \\
\text { our group support } \\
\text { (this is really } \\
\text { going to happen!) } \\
\text { made it more } \\
\text { powerful. }\end{array}$ \\
\hline
\end{tabular}

Note. Source: Darief, T. (2011). Verfremdung in management education: initiating critical reflection (Doctoral dissertation). (pp. 96-142). Macquarie University, Macquarie Graduate School of Management, Sydney, Australia.

Nearly all of the students expressed some degree of shock and criticism of the open and flexible format of the course, and the lack of focus on the provision of methods and tools for managing change. As one student remarked "I have found it easy and natural to be logical and rational", with many reflecting after the course that, as one other student observed, "There is an emotional journey in managing change, that implies reflection and even some discomfort". For those more strongly focused on the acquisition of tools and techniques, a key focus was on the acquisition of mapping techniques and an acquired knowledge of the importance of impression management techniques, such as the need for "adapting to a communication style appreciated by the audience rather than displaying the emotions". For many, there was a recognition from thee performances they were required to give, that there is "a lot of work in the group around the content, structuring, props and so on", observing that it became "clear how different body language, tone, confidence, pausing, and expression can impact a discussion."

For many, such insights were more a reinforcement of what they, at least tacitly already know, making comments such as "It confirmed ..." or that the framework was "Reiterating what I had learned in prior change management programs". In this sense, the framework achieved resonance less through disruption and shock, and more with confirming and elaborating prior expectations and understandings, while moving students into a thicker view of rationality and a greater recognition of performativity, even though often in a weak form. For others, however, the effect was seen to be more disruptive. As one student remarked "I have to unfreeze my way of thinking and learn to appreciate this new way of learning". Students adopting either perspectives commented on the importance of moving beyond the view of having a "template to memorise and apply in every single situation", and "to look deeper into the situation and ensure that I have considered as many elements as I can identify". Many affirmed that "the process and the emotions you go through are the same", as you have to mobilize energy, resources and people for a recognisably unpredictable change journey. The tools of mapping journeys were 
understood not as a rigid project plan but as a looser set of means for guiding and reflecting on change; i.e. "with a map we would be given orientation and guidance for our change initiative ... Further these maps will allow for reflection and a chance to discuss whether there should be a change in direction in the near future". Wearing masks was considered "vitally important" for the delivery of an effective change performance, and the effective use of mirrors regarded as a key to improving that performance, observing that "Taking a good hard look at myself, I can see that I have certain habits that I need to navigate away from or change".

\section{Conclusion}

The purpose of this paper has been threefold:

1. to introduce a comprehensive framework for guiding thought and action about managing change that transcends the limitations of traditional change management;

2. to describe the rhetorical elements employed in order to communicate this framework to experienced managers in an MBA course environment; and

3. to flesh out the character and impact of the framework by providing examples of the understanding and variable responses to this framework of the student audience.

Within the 47 students whose learning diaries were surveyed, the smallest group (10) showed partial progress mainly from a thin to a thick view of rationality and change; the second largest group (13) showed a significant degree of movement from a thin to a thick view, as well as incorporating elements of the weak understanding of change as drama and performance; while the largest group (24) showed evidence of having progressed from thin to thick views of rationality and change, as well as elements of both weak and strong views of change as drama and performance.

These responses to the course cannot be attributed solely to the framework. They do, however, indicate a degree of cultural resonance with the $5 \mathrm{M}$ framework amongst experienced mature middle managers. This is revealed in the amount of recognition given to complex and critical views of knowledge and rationality, and the performative nature of organisational life.

As captured in Amanda Sinclair's (2007) description of Teaching Leadership Critically to MBAs: Experiences from Heaven and Hell, there are substantial risks in trying to teach leadership and change critically to experienced managers. Initial experiences of anxiety, strangeness and political suspicion can lead to responses ranging from grudging resentment to active resistance and opposition. The 5M framework seeks to address this situation by unfreezing managerialist biases through an appeal to experiences of the pragmatic irrationalities and challenges of managerial life, as well as the implicit, and often explicit, recognition of the centrality of impression management, storytelling and stagecraft. Rather than focusing on authoritatively educating students on the controversial ethics of leadership, or the objective workings of power, it initiates a dialogue on the personal meaning of organisational life and career in the face of experiences of organisational irrationality and theatricality. The positive response of the students, accompanied by their varying levels of effective translation of the framework, indicates that the $5 \mathrm{M}$ approach has the capacity to engage managers in a process that both encourages reflection and provides them with pragmatic assistance in managing change. A realist form of critical management may question whether such an approach gives sufficient recognition to the centrality of domination and control in managerial life. In narrower terms, however, the 5M framework incorporates issues of power and domination through the focus on the Mobilisation of energy, the Mapping of political forces of change, and the deployment of Masks that can only be made to appear authentic and achieve resonance if they are not perceived as tools of power. More broadly, however, as supporters of a critical performativity emphasise (Spicer, Alvesson, \& Karreman, 2009, p. 538), an alternative view to traditional critical management views is one that is more involved in "active and subversive intervention into managerial discourses and practices. This is achieved through affirmation, care, 
pragmatism, engagement with potentialities, and a normative orientation". The 5M framework is offered as a practical working example of such an intervention.

Further research might follow up on a number of key themes, issues and questions raised by this study.

Firstly, it would be desirable to capture and assess the impact of other frameworks deployed to communicate a non-traditional view of change management to practicing managers. It is hoped that this study will stimulate others to undertake a similar kind of assessment. Secondly, further research is required on the reason for different student responses to such rhetorical frameworks. In this study, no differences were found in the age, gender or demographic character of the different groups, but further exploration of individual personality and professional and institutional location would be highly advantageous. Thirdly, and finally, the framework has employed general criteria of thin and thick rationality, and weak and strong views of drama and performance in organisations, to describe the framework and assess the responses. Further development and operationalisation of these criteria, and the use of these to further refine the rhetorical framework as well as guide a more structured exploration of its impact, would be extremely valuable.

\section{References}

Alexander, J. C. (2004). Cultural pragmatics: social performance between ritual and strategy. Sociological Theory, 22(4), 527-573. doi: 10.1111/j.0735-2751.2004.00233.x

Alexander, J. C., \& Smith, P. (2003). The strong program in cultural sociology: elements of a structural hermeneutics. In J. C. Alexander (Ed.), The meanings of social life: a cultural sociology (Chapter 1, pp. 11-26). New York: Oxford University Press.

Argyris, C. (2010). Organizational traps: leadership, culture, organizational design. New York: Oxford University Press.

Ariely, D. (2008). Predictably irrational: the hidden forces that shape our destiny. New York: HarperCollins.

Badham, R., Mead, A., \& Antonacopoulou, E. (2012). Performing change: a dramaturgical approach to the practice of managing change. In D. M. Boje, B. Burnes, \& J. Hassard (Eds.), The routledge companion to organizational change (pp. 187-205). London and New York: Routledge.

Beckhard, R. (1969). Organization development: strategies and models. Boston, MA: Addison-Wesley Publishing.

Bennis, W. G. (1969). Organization development: its nature, origins and prospects. Boston, MA: Addison-Wesley Publishing.

Boal, A. (1979). Theater of the oppressed. New York: Theatre Communications Group.

Brock, B. L., Burke, K., Burgess, P. G., \& Simons, H. W. (1985). Dramatism as ontology or epistemology: a symposium. Communication Quarterly, 33(1), 17-33. doi: $10.1080 / 01463378509369575$

Bruch, H., \& Vogel, B. (2011). Fully charged: how great leaders boost their organizations energy and ignite high performance. Boston: Harvard Business Review Press.

Buchanan, D., \& Boddy, D. (1992). The expertise of the change agent: public performance and backstage activity. New York: Prentice Hall. 
Buchanan, D., \& Badham, R. (2008). Power, politics and organizational change: winning the turf game. London: Sage.

Burke, K. (1969). A grammar of motives. Berkeley: University of California Press.

Burke, K. (1984). Attitudes toward history. Los Angeles: University of California Press.

Clark, T., \& Mangham, I. (2004). From dramaturgy to theatre as technology: the case of corporate theatre. Journal of Management Studies, 41(1), 37-59. doi: 10.1111/j.1467-6486.2004.00420.x

Collins, D. (1998). Organizational change: sociological perspectives. London: Routledge.

Czarniawska-Joerges, B. (1997). Narrating the organization: dramas of institutional identity. Chicago: University of Chicago Press.

Darief, T. (2011). Verfremdung in management education: initiating critical reflection (Doctoral dissertation). Macquarie University, Macquarie Graduate School of Management, Sydney, Australia.

Dawson, P. (2003). Understanding organisational change. London: Sage.

Edgley, C. (2003). The dramaturgical genre. In L. T. Reynolds, \& N. J. Herman-Skinney (Eds.), Handbook of symbolic interactionism (Chapter 6, pp. 141-172). New York: Rowman \& Littlefield.

Foss, N. (2001). From thin to thick bounded rationality in the economics of organization: an explorative discussion [WP 2001-3]. Institut for Industriфkonomi og Virksomhedsstrategi, Copenhagen Business School, Denmark.

Freire, P. (1987). Pedagogia do oprimido (17th ed.). Rio de Janeiro: Paz e Terra.

Fuda, P., \& Badham, R. (2011, November). Fire, snowball, mask, movie: how leaders spark and sustain change. Harvard Business Review, 89(11), 145-148.

Geertz, C. (1973). The interpretation of cultures: selected essays. New York: Basic Books.

Goffman, E. (1959). The presentation of self in everyday life. New York: Anchor Books.

Grint, K. (2001). The arts of leadership. New York: Oxford University Press.

Harre, R., \& Secord, P. F. (1973). The explanation of social behaviour. Totowa, NJ: Littlefield.

Hendry, C. (1996). Understanding and creating whole organizational change through learning theory. Human Relations, 49(5), 621-641. doi: 10.1177/001872679604900505

Heracleous, L., \& Barrett, M. (2001). Organizational change as discourse: communicative actions and deep structures in the context of information technology implementation. The Academy of Management Journal, 44(4), 755-778. doi: 10.2307/3069414

Jabri, M. (2012). Managing organizational change: process, construction and dialogue. London: Palgrave/Macmillan.

Kanter, R. M. (2002). Strategy as improvisational theater. MIT Sloan Management Review, 43(2), 76-81.

Kärreman, D. (2001). The scripted organization: dramaturgy from Burke to Baudrillard. In R. I. Westwood, \& S. Linstead (Eds.), The language of organization (pp. 89-111). London: Sage.

Kotzee, B., \& Wanderer, J. (2008). Introduction: a thicker epistemology? Philosophical Papers, 37(3), 337-343. doi: 10.1080/05568641.2008.10510725 
Langer, E. J. (1990). Mindfulness. Cambridge: Da Capo Press.

Lanham, R. A. (1993). The electronic word. Chicago: University of Chicago Press.

Long, M. (2010). Derrida and a theory of irony: parabasis and parataxis (Doctoral dissertation). Durham University, United Kingdom. Retrieved from http://etheses.dur.ac.uk/665/

Mangham, I. L., \& Overington, M. A. (1983). Dramatism and the theatrical metaphor. In G. Morgan (Ed.), Beyond the method: strategies for social research (Chap. 19, pp. 219-233). Beverly Hills: Sage.

Mangham, I. L., \& Overington, M. A. (1987). Organization as theatre: a social psychology of dramatic appearances. Chichester: John Wiley \& Sons.

Mangham, I. L., \& Pye, A. (1991). The doing of managing. Oxford, UK: Blackwell Publishing.

March, J. G. (1981). Footnotes to organizational change. Administrative Science Quarterly, 26(4), 563577. doi: $10.2307 / 2392340$

March, J. G. (1994). A primer on decision making: how decisions happen. New York: Free Press.

March, J. G., \& Olson, J. P. (1983). Organizing political life: what administrative reorganization tells us about government. American Political Science Review, 77(2), 281-296.

McCloskey, D. N. (1994). Knowledge and persuasion in economics. New York: Cambridge University Press.

Meyer, J. W., \& Rowan, B. (1977). Institutionalized organizations: formal structure as myth and ceremony. American Journal of Sociology, 83(2), 340-363.

Mintzberg, H. (2009). Managing. San Francisco: Berrett-Koehler Publishers.

Morgan, G. (1980). Paradigms, metaphors and puzzle solving in organization theory. Administrative Science Quarterly, 25(4), 605-622. doi: 10.2307/2392283

Pfeffer, J. (1994). Managing with power:politics and influence in organizations. Boston: Harvard Business School Press.

Schein, E. H. (1969). Process consultation: its role in organization development. Boston: AddisonWesley Publishing.

Schreyogg, G., \& Hopfl, H. (2004). Theatre and organization: editorial introduction. Organization Studies, 25(5), 691-704. doi: 10.1177/0170840604042410

Sense, A. (2008). Cultivating the learning within projects. London: Palgrave Macmillan.

Sinclair, A. (2007). Teaching leadership critically to MBAs: experiences from heaven and hell. Management Learning, 38(4), 458-472. doi: 10.1177/1350507607080579

Spicer, A., Alvesson, M., \& Karreman, D. (2009). Critical performativity: the unfinished business of critical management studies. Human Relations, 62(4), 537-560. doi: 10.1177/0018726708101984

Stacey, R. (2012). Tools and techniques of leadership and management: meeting the challenge of complexity. London: Routledge.

Turner, V. R. (Ed.). (1985). On the edge of the bush: anthropology as experience. Tucson: University of Arizona Press.

Turner, V. W. (1982). From ritual to theatre: the human seriousness of play. New York: PAJ. 
Vera, D., \& Crossan, M. (2004). Theatrical improvisation: lessons for organizations. Organization Studies, 25(5), 727-749. doi: 10.1177/0170840604042412

Waltzer, M. (1994). Thick and thin: moral argument at home and abroad. London: University of Notre Dame Press.

Weber, M. (1947). The theory of social and economic organization. New York: Free Press.

Weick, K. E. (2000). Making sense of the organization. Oxford: Wiley-Blackwell.

Weick, K. E., \& Quinn, R. E. (1999). Organizational change and development. Annual Review of Psychology, 50, 361-386. doi: 10.1146/annurev.psych.50.1.361

Weick, K. E., \& Sutcliffe, K. M. (2001). Managing the unexpected: assuring high performance in an age of complexity. San Francisco, CA: Jossey-Bass.

Zafirovsky, M. (2003). Human rational behavior and economic rationality. Electronic Journal of Sociology, 2, 1-31. Retrieved from http://www.sociology.org/content/vol7.2/02_zafirovski.html

\title{
Authors' Profiles
}

\author{
Richard Badham \\ Macquarie Graduate School of Management, North Ryde, Sydney, NSW, 2109, Australia. E-mail address: \\ richard.badham@mgsm.edu.au \\ Vera L. Cançado \\ Av. Lincoln Diogo Viana, 830, Pedro Leopoldo, MG, Brazil. E-mail address: vera.cancado@fpl.edu.br \\ Temi Darief \\ Macquarie Graduate School of Management, North Ryde, Sydney, NSW, 2109, Australia. E-mail address: \\ temidarief@gmail.com
}

